\title{
Address of the new editor
}

\section{Georg Hirte}

(C) Springer-Verlag Berlin Heidelberg 2013

For about two decades Klaus Schöler had been the editor of the Jahrbuch für Regionalwissenschaft/Review of Regional Research. This is the journal of the Gesellschaft für Regionalforschung (GfR), i.e. the German speaking section of ERSA/RSAI. It was his achievement that the Journal is today well established in the German speaking world of regional science and also became known in the international regional science community. Though the Journal is small there have been more than 5500 downloads last year with a considerable share from outside of the German speaking world. During this period the share of papers published in English increased, the Journal was given a second name in English and Springer became the publisher. Simultaneously the world of regional science has changed a lot. A number of new journals have been founded some of them are now leading journals in regional science, the impact factor has become much more important, and young scientists are now publishing only in English.

In February 2013 the German speaking section appointed me to act as the new editor-in-chief of the Jahrbuch für Regionalwissenschaft (JFRE). It will be the aim for the next future to establish the journal in this more competitive world. The first stages into that direction are done: authors submit their contributions now via the editorialmanager system of Springer (https://www.editorialmanager.com/jfre/default.asp) and thirty six of well-known scholars from various fields of regional science have agreed to act as member in the new Editorial Board. The first meeting of that Board took place at the ERSA congress in Palermo. Further, Review of Regional Research will be the main name of the journal as off the first issue in 2014 and the current German name will become the 2nd name. JFRE can be also found via the new ERSA Journal

G. Hirte $(\bowtie)$

TU Dresden, Dresden, Germany

e-mail: georg.hirte@tu-dresden.de 
page (http://www-sre.wu.ac.at/ersajournals/test.html) and off course in many search machines like SCOPUS etc.

JFRE focuses on an interdisciplinary community. Contributions from the fields of economics, geography, sociology, planning, transportation science and environmental research will be welcome if their focus is on regions or cities. To underline that JFRE is the journal of the German speaking section (GfR) it still will be possible to submit papers written in German. However, if the paper is of interest to the international readers I will ask the authors to translate the paper into English and submit it again. Papers shall follow scientific standards in their specific subfield and it will be possible to publish contributions that apply already known studies to other countries, regions or reproduce them with new data. I also encourage authors to submit surveys on important topics in the field.

It is a challenge to steer the journal through this competitive world and it cannot be done without the support by the GfR, the Editorial Board and Springer, and of course the work of authors, reviewers, and readers. I feel confident that with all your support this journal can provide a decent platform for regional research that will fit nicely in the world of journals in the field.

This current issue is some kind of co-production. Half of the papers have been accepted by the former editor and the other half by me. Therefore it is the opportunity to express my gratitude to Klaus Schöler, his team, the various reviewers and Springer for the work they did for the Jahrbuch für Regionalwissenschaft.

Dresden, September 2013

Georg Hirte 